\title{
Assessment of Relationship Between Inflation, Growth and Fiscal Deficit in Albania-An Econometric Approach
}

\author{
Mira Andoni, Dr. \\ Professional Academy of Business, Tirana Albania \\ Myslym Osmani, Prof. Dr.
}

Agricultural University of Tirana, Faculty of Agribusiness, Tirana, Albania

doi: 10.19044/esj.2017.v13n13p137 URL:http://dx.doi.org/10.19044/esj.2017.v13n13p137

\begin{abstract}
The relationship between variables growth, inflation and fiscal deficit is largely debated in economic theory; it is studied also empirically. Both theory and ground research suggest negative relationship between growth and inflation, and between inflation and budget deficit, while there is a controversy about relationship between budget deficit and growth. Based on that, IMF suggests programs of macroeconomic stabilization for countries in course of development like Albania. The IMF expertise and support has been available in Albania through bilateral cooperation programs for more than 20 years beginning in 1991. Support of IMF to Albania has been qualified as success. In our research we study the relationship between the three variables, based on Albanian time series data on these variables. We used classical time series regression and stationary time series models, as well ARDL, threshold and switching regression models to investigate these relationships. Our results support the negative relationship between inflation and growth, a positive relationship between inflation and deficit, but we didn't discover any relationship between fiscal deficit and growth. A threshold nonlinear relationship best describes dependence between growth and inflation.
\end{abstract}

Keywords: Growth, Inflation, econometric model, threshold, switching regression

\section{Introduction}

\section{Problem situation}

Albania is a small SEE country with almost 3 million people and 28 thousands $\mathrm{km}$ squares of land. Till 1990 it was under communism and it suffered one of the harshest communist regimes in Europe. After 1990 a 
democratic regime was established and country entered the road of radical economic reforms. Privatization and price liberalization were the first among them. They begin as early as 1991 (land reform and privatization of companies), and 1992 (price liberalization). As a result, an economic transformation began and both output and prices started to increase.

One of the most important basic objectives for many countries is to sustain high economic growth with low inflation and reduced budget deficit. This objective has been supported also by the IMF through design and support of stabilization programs. This is justified by the view that low inflation and reduced deficit promote development through macroeconomic stabilization.

In this context, Albania started cooperation with IMF. Albania first joined IMF in 1991. First agreement with IMF was the Standby Agreement in year 1992. In 1993 another agreement was reached, Enhanced Structural Adjustment Facility (ESAF). Other cooperation agreements followed and so far 8 agreements have been signed with IMF. In 2009 the active cooperation with IMF passed onto a bilateral consultation status. Last mission of IMF in Albania was in 2011. But in 2014 Albania and IMF re-launched a new phase of mutual cooperation with a new 3-year agreement for years 2014-2016. One of the main and constant suggestions of IMF for Albania has been to implement a restrictive financial policy, aiming at keeping constantly low inflation and control of budget deficit, as means to achieve macroeconomic stability and create an investment environment. Assessment done periodically by IMF itself for the impact of its programs in Albania, considers Albania by large a remarkable success story.

\section{A little about Theory}

Theoretically there has been always a wide debate about reciprocal effects of GDP growth, inflation and fiscal deficit is still continuing This debate has been and still continues to be among others about two major issues; first, which are the transmission mechanism of effects from one variable to the other, and, second, which is the direction of effects, that is effects are only unilateral, from variable to the other, or they are bilateral. Both issues have a theoretical explanation, coming from the ground works of the economics science, and an empirical explanation, based on ground evidence.

Dornbusch and Fischer, (1994) argue that inflation rate and output are dependent on both aggregate demand and supply; that means on factors influencing on these aggregates. Increase in money supply (which may happen because an increase in government expenses or rate of money supply, leads to both an increase in inflation and output. 
Keynesian theory has as main focus government spending as an instrument to stimulate growth. Classical economics recalls supply-side theories, which emphasize the need for incentives to save and invest if the nation's economy is to grow. Monetarism emphasize the critical role of monetary growth in determining inflation, while neoclassical and endogenous growth theories account for the effects of inflation on growth through its impact on investment and capital accumulation, (see Gokal and Hanif, 2004).

A considerable debate has been between structuralism and monetarism on the nature of the inflation and economic growth relationship over the past few decades. Structuralism believes that inflation is essential for economic growth, where as the monetarists see inflation as detrimental to economic growth. Some findings say there is significant short-run relationship but not in the long-run, (see Datta and Kumar, 2011b).

There are three views about growth-budget deficit relationship. Keynes says that there must be a positive relation between budget deficit and economic growth while neo-classical views that there is an inverse relationship. Ricardo says that there is neutral relation between budget deficit and economic growth, (see Ahmad, 2013). And higher taxes mean less economic growth, Alesina and Rodrik, (1994).

Let's first try to explain said effects based on economics theory. The first link in consideration is that between growth and inflation. Stable inflation is considered by IMF, but not only, one of the pivots of the macroeconomic stability of a country. And higher inflation, that might result from increased money supply and government spending, tends to bring about more uncertainty in the business environment, mal-investment, an increase in interest rates in the long run, so higher cost of borrowing and as a result less borrowing and investment. All this can discourage production or do harm to growth in long run. If significant part of inflation comes from higher prices of energy, then we would have higher production costs and possible reduced supply of goods and services. All this tends to contract GDP growth rate. So theoretically it is expected a negative relationship between inflation and growth rate. On the other side, high rates of growth stimulate employment; but companies might not find enough and suitable workforce to employ and this could lead to increased wages of the existing workforce. In any case, companies spend more money for wages and salaries. This leads to an increase of demand for consumer goods, but also prices, thus higher inflation.

The second link in consideration is that between fiscal deficit and growth. High fiscal deficit means that considerable part of government undertakes, that is spending and investment, are financed by borrowed, or printed money. Cost of borrowing must be paid, through payment of principals and interests in upcoming years, which is an extra burden for the 
budget. Usually, government is less efficient than private, and effects of investment on growth will be lower. More, government may spend money in non-yielding or luxury projects, raise public employees' salaries, and unreasonably buy arms. Moreover, government spending or investment may crowd out private spending. All this could have a negative effect of high budget deficit on growth. On the other side, high growth rates can lead to increased government revenue from taxes, and tend to stabilize government budget ceteris paribus; so higher growth rates tend to have a negative effect on fiscal deficit.

The last link in consideration is that between fiscal deficit and inflation. Fiscal deficit means more money in circulation (more government investment and spending). And since inflation is a monetary phenomenon, the result of increased budget deficit is inflation. On the other side, if government fails to collect taxes in time, tax due as of today and collected at a later time is devaluated because of inflation. This has a negative effect on the fiscal deficit. So, higher inflation is expected to have a positive effect that means increasing effect on budget deficit.

\section{From the empirical research}

Let's now turn to ground evidence. Ground research about reciprocal relationship between growth, inflation and fiscal deficit is extremely abundant, and almost in any part or country in the world. And we can nothing do but touch only a tiny part of it.

Generally speaking, the empirical evidence shows that growth and inflation are negatively correlated; higher inflation is associated with lower growth because lower real balances reduce the efficiency of factors of production, and because there may be a link between government purchases and the use of the inflation tax (Fischer, 1983). Barro (2013) used data for 100 countries from 1960 to 1990 and found that an increase in average inflation by 10 percentage points per year leads to a reduction of the growth rate of real per capita GDP by 0.2-0.3 percent per year. Ghosh, Philips (2004), state that there is no doubt that very high inflation is bad for growth, there is much less agreement about moderate inflation effects. They find a statistically and economically significant negative relationship between inflation and growth. Andrés, Ignacio ( $)$, analyzed link between growth and inflation in OECD countries during the 1960-92 period and he found that even low or moderate inflation rates have a temporary negative impact on growth rates. Inflation not only reduces the level of business investment, but also the efficiency with which productive factors are put to use. The benefits of lowering inflation are great, according to the authors, but also dependent on the rate of inflation. The lower the inflation rate, the greater are the productive effects of a reduction. However, the negative correlation among 
growth and inflation is not explained by the experience of high-inflation economies and the observed correlation cannot be dismissed on the grounds of reverse causation (from GDP to inflation). Min, ( ), studied the form of relationship between inflation and growth. To this end, he used data from 90 developing countries and 28 developed countries over the period 1961-2004; he found that relationship between inflation and economic growth is nonlinear. Further investigation suggests that developing countries and developed countries show different forms of nonlinearity in the inflationgrowth relationship and the size of the negative effect of inflation on growth declines as the inflation rate increases. Fikirte, Tsegaye, Mamo (2012), used data which from13 SSA countries from 1969 to 2009. Economic growth ir regressed on four variables (i.e. inflation, investment, population and initial GDP) as independent variables. The result indicates that there is a negative relationship between economic growth and inflation. Kasidi et al. (2013), made a study about Tanzania, examining time-series data for the period 1990 -2011 and he also established an empirical relationship between inflation and GDP. Pollin, Zhu, (2006), used a non-linear regression to estimate relationship between inflation and economic growth for 80 countries over the period 1961-2000; they also investigated separately OECD countries, middle-income countries, and low-income countries. Based on full data set they found that higher inflation is associated with moderate gains in GDP growth up to a roughly 15-18 percent inflation threshold. Thanabalasingam, Vinayagathasan (2013), investigates the existence of a threshold level for inflation and how any such level affects the growth of Asian economies. They found a nonlinear relationship between inflation and economic growth for 32 Asian countries over the period 1980-2009. Gilman, Harris, Matyas ( ), estimated model based on a panel of OECD and APEC member countries over the years 1961-1997 and the research suggests a negative inflationgrowth effect, and one that is stronger at lower levels of inflation. Pradana et al. (2013), tested the link between Inflation and Economic Growth in the context of Asia. They investigate the short-run and the long-run relationship between the economic growth and the inflation of three Asian courtiers over the period 1980-2010. The results reveal that there is a long run negative and significant relationship between the economic growth and inflation in Sri Lanka and a negative and significant short run relationship was found for China. Faria, Caneiro, (2001), have investigated the relationship between inflation and growth in the context of an economy facing persistent high inflation, as Brazil. They found that inflation does not impact real output in the long run, but that in the short run there exists a negative effect from inflation on output. Gokal, Hanif (2004), found a weak negative correlation exists between inflation and growth in Fiji. In Romania, investigations show 
that, controlling inflationary phenomenon since 2000 has led to positive rates of GDP growth, Lupu, ( ).

As for the relationship between inflation and budget deficit, Solomon et.al (2004) point out, due monetization of the budget deficit, significant inflationary effects are found for increases in the budget deficit. Datta, Kumar, (2011a) as well investigated the relationship between budget deficits and inflation using annual data of Indonesia from 1971 to 1999, this study found an existence of a stable long-run relationship between inflation and Budget Deficit. This study also shows that there exists a unidirectional causality from Inflation to BD over the period of the study in Indonesia. There is a short-run causality between the variables and direction of causality is from inflation to economic growth but in the long-run economic growth causes inflation. Metin, (1998) found for Turkey that an increase in the scaled budget deficit immediately increases inflation. Real income growth has a negative immediate effect and positive second-lag effect on inflation. Monetization of the deficit has effect on inflation but at second lag.

Concerning the third aspect, that of relationship between budget deficit and economic growth we bring the contribution of Fatima, Ahmed, Rehman, (2012), who studied impact of budget deficit on economic growth in Pakistan; they used time series and found a negative impact of budget deficit on the economic growth. Ahmad, (2013), also studied but Pakistan case. A time series data for the period of 1971-2007 has been used to check the relation between budget deficit and economic growth of Pakistan. The results show that there is a two-way causality, from budget deficit to GDP and vice-versa. Nayab (2015), examined the impact of budget deficit on economic growth in Pakistan during the period from 1976-2007. They show that all variables are co integrated and error correction term is also significant. However they have not found any significant impact of budget deficit on economic growth of Pakistan. Hayati and Rahman, (2012), investigate the relationship between budget deficit and economic growth in Malaysia. Using quarterly data from 2000 to 2011, they found that there is no long-run relationship between budget deficit and economic growth of Malaysia, consistent with the Ricardian equivalence hypothesis. Reinhart, Rogeoff, (2010) studied a new multi-country dataset to investigate link of government debt to public debt, growth and inflation. The conclusion was that link between growth and debt seems relatively weak at "normal" debt levels, median growth rates for countries with public debt over roughly 90 percent of GDP are about one percent lower than otherwise; the relationship between public debt and growth is remarkably similar across emerging markets and advanced economies. This was not the case for inflation; there wasn't any systematic relationship between high debt levels and inflation for 
advanced economies as a group. But in emerging market countries, high public debt levels coincide with higher inflation.

To summarize, most of empirical research supports the idea of negative relationship between growth and inflation, but various types of findings exist. The general finding is that between growth and inflation there is a negative relationship. In some cases even low or moderate inflation rate have an impact on growth rate. In developed countries there isn't evidence that such a correlation exists. Relationship between inflation and economic growth might be nonlinear. Developing countries and developed countries show different forms of nonlinearity in the inflation-growth relationship and the size of the negative effect of inflation on growth declines as the inflation rate increases. Some authors advance the idea of a threshold in the dependence growth-inflation. In a case, higher inflation is associated with moderate gains in GDP growth up to a roughly 15-18 percent inflation threshold. In a case, association between growth and inflation is negative but stronger at lower levels of inflation. Control of inflation, as recommended by IMF, (Albania is one case), has been effective vis-à-vis growth in some countries. In some cases inflation could be in short run relationship with growth, but in some other also in long run relationship.

As for deficit-growth aspect, we have three types of findings: relationship between public debt and growth is quite similar across emerging markets and advanced economies; there is no association between growth and deficit; there is an association between growth and inflation.

And last, there isn't any systematic relationship between high debt levels and inflation for advanced economies, but in emerging market countries, high public debt levels coincide with higher inflation.

\section{Research problem and questions}

Our research problem is the need to know what are in the case Albania reciprocal effects of growth, inflation and fiscal deficit. We want to empirically, inter alias econometrically, assess the role of inflation and budget deficit control as suggested and maintained constantly by IMF on GDP

These are the questions we want to give an answer:

1. Is there a statistical relationship between growth, inflation and fiscal deficit in Albania? Whether linear or non-linear? Whether negative or positive?

2. Is there an inflation threshold value that determines regime-specific regressions?

3. What is, if any, the tolerable inflation rate as to have non-negative effect on GDP growth rate?

4. What are the chances of growth rates to lie in specific regimes? 
5. Is there any time lag at which inflation influences GDP growth rate?

6. What are, if any, short-run and long-run impact multipliers of inflation on GDP?

7. At last, is Albania an IMF success story in achieving effective macroeconomic stabilization?

\section{Methods and data}

Researchers across different parts of the worlds have investigated links between inflation, growth and budget deficit. Various research techniques have been used by different authors. Just to mention a few of them, Barro (2013), Fatima, Ahmed, Rehman, (2012), Metin, (1998), Ahmad, (2013), Datta, Kumar, (2011a,b), Nayab (2015), Pradana et al. (2013) used cointegrating techniques, ADF and Granger Casuality tests, ADF, PP Unit, Root Test, Vector Error Correction, Vector Auto Regression, Impulse response function and Variance Decomposition techniques; Hayati and Rahman, (2012), used an ARDL; Fikirte Tsegaye Mamo, (2012), Thanabalasingam, Vinayagathasan (2013), Ghosh, Philips (2004), used dynamic panel threshold growth regression and assumed nonlinear relationship between inflation and economic growth.

Our research approach is empirical econometric evaluation. In our research we use both linear and nonlinear econometric modeling, ARDL models, threshold and Markov switching regression models. For theoretical background on regression with time series refer to Gujarati (2004), Wooldridge (2009), Eviews User's Guide II (2015). For threshold and switching models refer to Brooks (2008). We used Eviews 9 to process data.

We use secondary data for GDP growth rates (shortly GR), budget deficits (shortly DEF) and inflation rate (shortly I) for years 1993-2015. Data are presented in Table 1.

Table 1: Data on Inflation rate (\%), Growth rate (\%) and budget deficit (\%) for years 19932015

\begin{tabular}{|c|c|c|c|c|c|c|c|}
\hline Year & I & GR & DEF & Year & I & GR & DEF \\
\hline 1993 & 30.9 & 9.6 & 13.7 & 2005 & 2 & 5.7 & 3.5 \\
\hline 1994 & 15.8 & 8.3 & 9 & 2006 & 2.5 & 5.4 & 3.3 \\
\hline 1995 & 6 & 13.3 & 10.2 & 2007 & 3.1 & 5.9 & 3.5 \\
\hline 1996 & 17.4 & 9.1 & 12.8 & 2008 & 3.4 & 7.7 & 5.5 \\
\hline 1997 & 42.1 & -7 & 12.9 & 2009 & 2.3 & 3.3 & 7 \\
\hline 1998 & 8.7 & 8 & 10.4 & 2010 & 3.56 & 3.71 & 3.1 \\
\hline 1999 & -1 & 7.3 & 11.5 & 2011 & 3.45 & 2.55 & 3.5 \\
\hline 2000 & 4.2 & 7.7 & 8.2 & 2012 & 2.04 & 1.42 & 3.4 \\
\hline 2001 & 3.5 & 6.5 & 7.9 & 2013 & 1.94 & 1.11 & 5 \\
\hline 2002 & 1.7 & 4.7 & 6.6 & 2014 & 1.63 & 2.02 & 5.2 \\
\hline 2003 & 3.3 & 6 & 4.5 & 2015 & 1.9 & 2.74 & 3.6 \\
\hline 2004 & 2.2 & 6 & 5.1 & 2016 & na & na & na \\
\hline
\end{tabular}




\section{Analysis and findings}

As following chart shows, all variables tend to stabilize and decrease over time. This suggests that the three series are not stationary.

Chart 1: Trends of GR, DEF and I in Albania over time

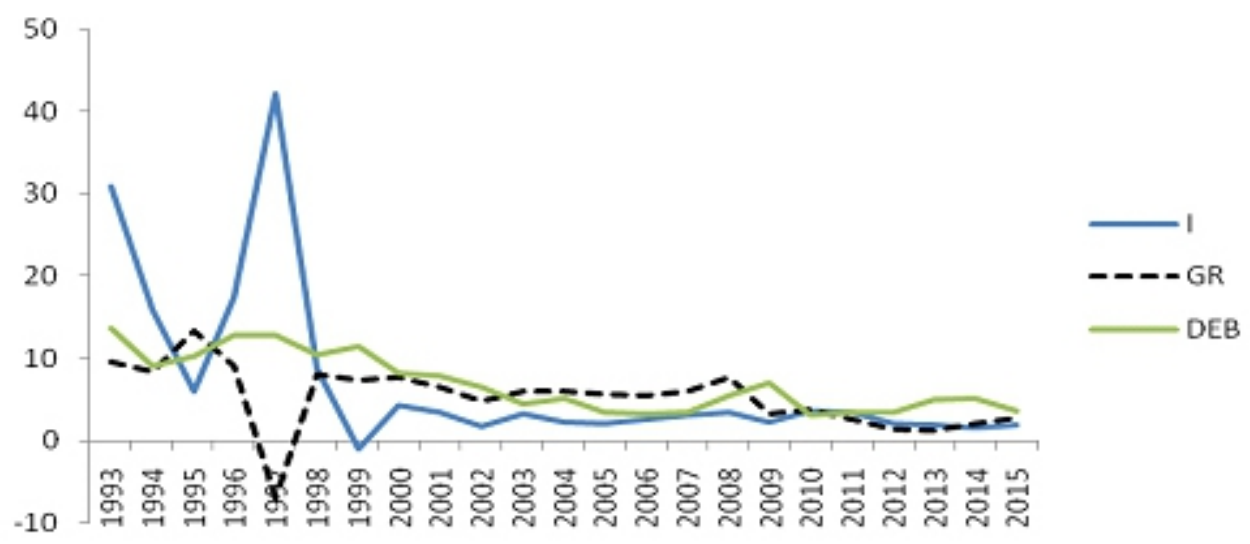

We performed the DF unit root test and/or Q test for stationarity. The results, as shown in Table 2, are that only first differences of the three variables, that are D (GR), D (DEF) and D (I), are stationary.

Table 2: Results of the DF tests of stationarity

\begin{tabular}{|c|c|c|c|c|c|c|}
\hline & $\begin{array}{c}\text { GR } \\
\text { t-Statistic }\end{array}$ & $\begin{array}{c}\mathrm{D}(\mathrm{GR}) \\
\mathrm{t}-\text { Statistic }\end{array}$ & $\begin{array}{c}\mathrm{DEF} \\
\mathrm{t} \text {-Statistic }\end{array}$ & $\begin{array}{c}\mathrm{D}(\mathrm{DEF}) \\
\mathrm{t}-\text { Statistic }\end{array}$ & $\begin{array}{c}\mathrm{I} \\
\text { t-Statistic }\end{array}$ & $\begin{array}{c}\mathrm{D}(\mathrm{I}) \\
\mathrm{t} \text {-Statistic }\end{array}$ \\
\hline $\begin{array}{c}\text { ADF test } \\
\text { value }\end{array}$ & 0.471 & -6.634 & -1.972 & -5.873 & -1.559 & -4.674 \\
\hline 5\% level & -3.040 & -3.012 & -3.005 & -3.012 & -3.021 & -3.030 \\
\hline
\end{tabular}

GR, DEF and I are not stationary; D (GR) is stationary, D (DEF) is stationary, D (I) is stationary

Then we estimate three basic linear regressions. First we regress I as a dependent variable on DEF, I on GR, DEF on I, and DEF on GR supposing there is a linear trend in data and removing it. The result is that effect of I on GR and DEF is statistically significant, DEF on I is significant and DEF on growth is not significant. See estimation results in Table 3.

Results show that between Inflation and Growth is a significant negative relationship; one percentage increase in inflation leads to -0.305 percent points decrease in Growth; between Deficit and Inflation there is a significant positive relationship, one percentage increase in Deficit leads to 2 percent points increase in Inflation. Between Deficit and Growth there is a non-significant negative relationship, one percentage increase in Deficit leads to 0.589 percent points decrease in Growth. Since the model is significant, we can conclude that the linear model can describe well the relationship between Inflation and Growth. 
Table 3: Results of estimation of relationship between GR, DEF and I.

\begin{tabular}{|c|c|c|c|c|}
\hline \multicolumn{5}{|c|}{$\mathrm{GR}=14.142-0.305 * \mathrm{I}-0.560 * \mathrm{YEAR}+\mathrm{e}_{2} \quad \mathrm{R}^{2}=0.653, \operatorname{Prob}(\mathrm{F})=0.000025, \mathrm{AIC}=4.752$} \\
\hline Variable & Coefficient & Std. Error & t-Statistic & Prob. \\
\hline $\mathrm{C}$ & 14.14216 & 1.533669 & 9.221133 & 0.0000 \\
\hline I & -0.305441 & 0.062273 & -4.904881 & 0.0001 \\
\hline YEAR & -0.559960 & 0.095227 & -5.880236 & 0.0000 \\
\hline \multicolumn{5}{|c|}{$\mathrm{I}=-6.385+2.005 * \mathrm{DEF}-0.037 * \mathrm{YEAR}^{2} \mathrm{e}_{3} \quad \mathrm{R}^{2}==0.488, \operatorname{Prob}(\mathrm{F})=0.00122, \mathrm{AIC}=7.062$} \\
\hline Variable & Coefficient & Std. Error & t-Statistic & Prob. \\
\hline $\mathrm{C}$ & -6.385384 & 10.77003 & -0.592884 & 0.5599 \\
\hline DEF & 2.005250 & 0.846816 & 2.367987 & 0.0281 \\
\hline YEAR & -0.036786 & 0.438380 & -0.083914 & 0.9340 \\
\hline \multicolumn{5}{|c|}{$\mathrm{GR}=15.812-0.589 * \mathrm{DEF}-0.539 * \mathrm{YEAR}+\mathrm{e}_{4}, \mathrm{R}^{2}=0.322, \operatorname{Prob}(\mathrm{F})=0.0205, \mathrm{AIC}=5.425$} \\
\hline $\begin{array}{l}\text { Variable } \\
\end{array}$ & Coefficient & Std. Error & t-Statistic & Prob. \\
\hline $\mathrm{C}$ & 15.81198 & 4.750333 & 3.328605 & 0.0033 \\
\hline DEF & -0.589274 & 0.373505 & -1.577688 & 0.1303 \\
\hline YEAR & -0.538751 & 0.193356 & -2.786318 & 0.0114 \\
\hline
\end{tabular}

Alternatively, we estimated the same (linear) models but based on first differences of the variables and found quite similar results in magnitude of effect as well as direction of the effects. See Table 4.

Table 4: Results of estimation of basic relationships based on first differences of variables.

\begin{tabular}{|c|c|c|c|c|}
\hline \multicolumn{5}{|c|}{$\mathrm{D}(\mathrm{GR})=-0.869-0.423 * \mathrm{D}(\mathrm{I})+\mathrm{e}_{1}, \mathrm{R}^{2}=0.7255$, Prob$(\mathrm{F})=0.0000, \mathrm{AIC}=4.965$} \\
\hline Variable & Coefficient & Std. Error & $\mathrm{t}-$ Statistic & Prob. \\
\hline $\mathrm{C}$ & -0.869124 & 0.596358 & -1.457385 & 0.1605 \\
\hline $\mathrm{D}(\mathrm{I})$ & -0.422783 & 0.058148 & -7.270790 & 0.0000 \\
\hline $\mathrm{D}(\mathrm{GR})=-0.846-0.426 * \mathrm{D}(\mathrm{I})+0.059 * \mathrm{D}(\mathrm{DEF})+\mathrm{e}_{2}, \mathrm{R}^{2}=0.726$, Prob(F)=0.00, AIC=5.054 \\
\hline Variable & Coefficient & Std. Error & $\mathrm{t}$-Statistic & Prob. \\
\hline $\mathrm{C}$ & -0.846301 & 0.624700 & -1.354731 & 0.1914 \\
\hline $\mathrm{D}(\mathrm{I})$ & -0.426057 & 0.062393 & -6.828587 & 0.0000 \\
\hline $\mathrm{D}(\mathrm{DEF})$ & 0.059113 & 0.332794 & 0.177626 & 0.8609 \\
\hline $\mathrm{D}(\mathrm{I})=-0.594+1.57 * \mathrm{D}(\mathrm{DEF})+\mathrm{e}_{3}$ & $\mathrm{R}^{2}=0.087$, Prob(F)=0.182, AIC $=7.567$ \\
\hline Variable & Coefficient & Std. Error & t-Statistic & Prob. \\
\hline $\mathrm{C}$ & -0.594906 & 2.234868 & -0.266193 & 0.7928 \\
\hline $\mathrm{D}(\mathrm{DEF})$ & 1.575451 & 1.139465 & 1.382623 & 0.1820 \\
\hline
\end{tabular}

Next we estimated a threshold regression model. One threshold was estimated, D (I) =-1.1 and two states were determined. For each state a specific linear regression was determined and estimated, but the whole model is non-linear, (two linear models with a threshold value), as in Table 5.

Table 5: Threshold regression for Growth

\begin{tabular}{|c|c|c|c|c|}
\hline \multicolumn{5}{|c|}{ Dependent Variable: $\mathrm{D}(\mathrm{GR})$} \\
\hline \multicolumn{5}{|c|}{ Method: Threshold Regression } \\
\hline \multicolumn{5}{|c|}{ Threshold type: Bai-Perron tests of L+1 vs. L sequentially determined thresholds } \\
\hline \multicolumn{5}{|c|}{ Threshold variable: $\mathrm{D}(\mathrm{I})$} \\
\hline \multicolumn{5}{|c|}{ Threshold selection: Trimming 0.15, , Sig. level 0.05} \\
\hline \multicolumn{5}{|c|}{ Threshold value used: -1.1} \\
\hline Variable & Coefficient & Std. Error & t-Statistic & Prob. \\
\hline \multicolumn{5}{|c|}{$\mathrm{D}(\mathrm{I})<-1.1--6$ observations } \\
\hline $\mathrm{C}$ & -3.302734 & 1.330129 & -2.483018 & 0.0231 \\
\hline $\mathrm{D}(\mathrm{I})$ & -0.489909 & 0.089673 & -5.463265 & 0.0000 \\
\hline \multicolumn{5}{|c|}{$-1.1<=\mathrm{D}(\mathrm{I})--16$ observations } \\
\hline
\end{tabular}




\begin{tabular}{|c|c|c|c|c|}
\hline C & 0.125936 & 0.712154 & 0.176838 & 0.8616 \\
\hline $\mathrm{D}(\mathrm{I})$ & -0.567282 & 0.099149 & -5.721540 & 0.0000 \\
\hline R-squared & $\mathbf{0 . 7 9 5 2 3 8}$ & Mean dependent variable & -0.311818 \\
\hline S.E. of regression & 2.525502 & \multicolumn{2}{|c|}{ Akaike info criterion } & 4.853722 \\
\hline F-statistic & 23.30229 & \multicolumn{2}{|l}{ Durbin-Watson stat } & 2.704737 \\
\hline Prob(F-statistic) & 0.000002 & & & \\
\hline
\end{tabular}

The model is:

\section{$\mathrm{D}(\mathrm{GR})=(\mathrm{D}(\mathrm{I})<-1.1) *(-3.3027-0.4899 * \mathrm{D}(\mathrm{I}))+(\mathrm{D}(\mathrm{I})>=-1.1) *(0.1259-$ $0.56728 * D(I))$}

We found that for the first state, that is for $\mathrm{D}(\mathrm{I})<-1.1$, an increase in $\mathrm{D}$ (I) for one unit, leads to a significant negative change in $\mathrm{D}$ (GR) of minus 0.4899 percentage change; for the second state, that is for $\mathrm{D}$ (I)>-1.1, an increase in $\mathrm{D}$ (I) for one unit, leads to a significant negative change in $\mathrm{D}$ (GR) of minus 0.5673 percentage change. The effect of Inflation on Growth is significant for any value of Inflation but it isn't constant over the whole period; it is results stronger in the second state. This means that a non-linear relationship of Growth on Inflation is more appropriate. This model also fits better our data (the determination coefficient is 0.795 against 0.7255 of the linear model. See tables 4 and 5). Thus, we can conclude that the nonlinear threshold regression model describes better the relationship between Inflation and Growth.

In the next step we estimated a switching (nonlinear) model with two hidden regimes, with regime specific regressions, as in Table 6.

Table 6: The switching model with two hidden regimes

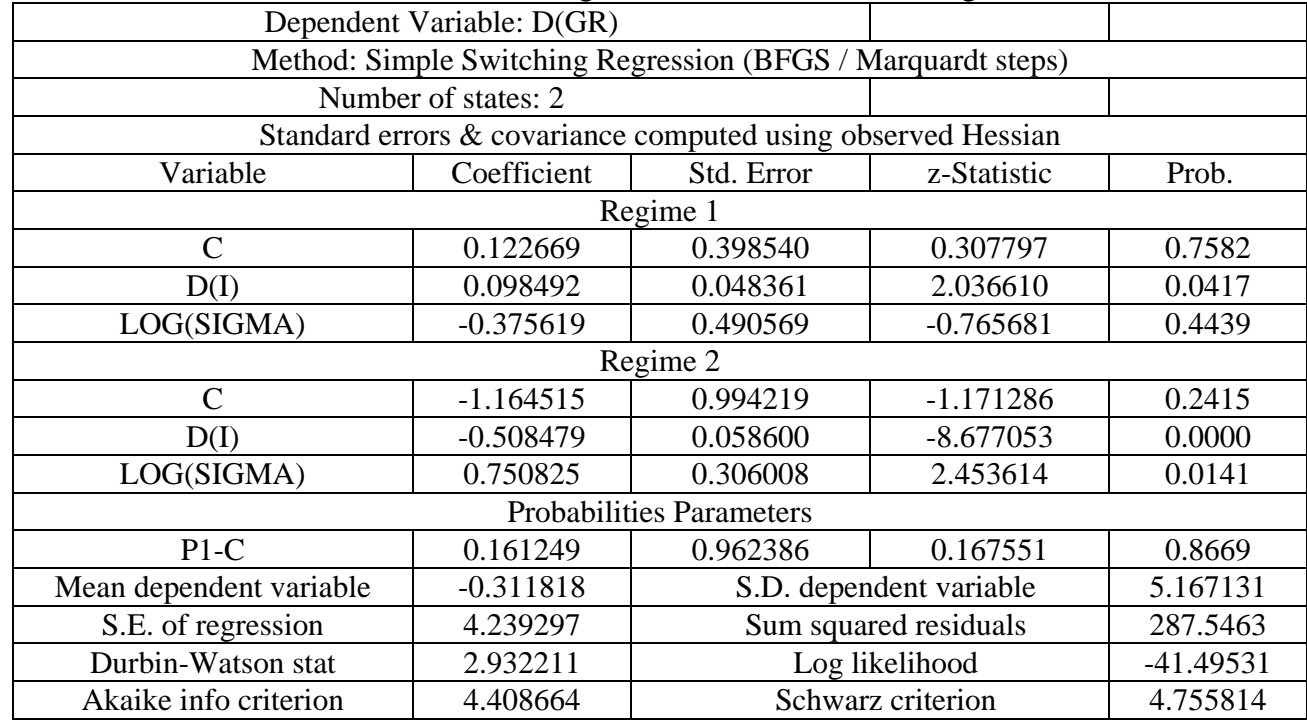


Regime 1: $G=0.1227+0.098 * D$ (I)

SIGMA = @EXP (-0.3756)

Regime 2: $\mathrm{G}=-\mathbf{1 . 1 6 4 5}-0.50845 * \mathrm{D}(\mathrm{I})$

SIGMA = @EXP (0.75082)

We found that in the first regime the effect of Inflation on Growth is positive and significant, and it is negative and significant in the second regime. We calculated the probabilities of regime one and regime two respectively 0.54 and 0.46, and expected duration of each duration 2.2 and 1.9 years respectively.

Probabilities for each regime in each year are presented in Table 7.

The conclusion here is that there have been also years over the period 1993-2015 when effect of inflation change D (I) on Growth rate has been positive. These are years with higher probabilities for regime one.

Table 7: Probabilities for regime one $\mathrm{P}(\mathrm{S}(\mathrm{t})=1)$ and regime two $\mathrm{P}(\mathrm{S}(\mathrm{t})=2)$

\begin{tabular}{|c|c|c|c|c|c|}
\hline Year & $\mathrm{P}(\mathrm{S}(\mathrm{t})=1)$ & $\mathrm{P}(\mathrm{S}(\mathrm{t})=2)$ & Year & $\mathrm{P}(\mathrm{S}(\mathrm{t})=1)$ & $\mathrm{P}(\mathrm{S}(\mathrm{t})=2)$ \\
\hline 1994 & 1.000 & 0.000 & 2005 & 0.765 & 0.235 \\
\hline 1995 & 0.000 & 1.000 & 2006 & 0.767 & 0.233 \\
\hline 1996 & 0.000 & 1.000 & 2007 & 0.834 & 0.166 \\
\hline 1997 & 0.000 & 1.000 & 2008 & 0.376 & 0.624 \\
\hline 1998 & 0.000 & 1.000 & 2009 & 0.000 & 1.000 \\
\hline 1999 & 0.970 & 0.030 & 2010 & 0.859 & 0.141 \\
\hline 2000 & 0.961 & 0.039 & 2011 & 0.395 & 0.605 \\
\hline 2001 & 0.411 & 0.589 & 2012 & 0.506 & 0.494 \\
\hline 2002 & 0.158 & 0.842 & 2013 & 0.763 & 0.237 \\
\hline 2003 & 0.799 & 0.201 & 2014 & 0.729 & 0.271 \\
\hline 2004 & 0.791 & 0.209 & 2015 & 0.802 & 0.198 \\
\hline
\end{tabular}

At last step we performed the ARDL analysis. The ARDL model we estimated is as in Table 8:

Table 8: the ARDL model for Growth

\begin{tabular}{|c|c|c|c|c|}
\hline \multicolumn{3}{|c|}{ Dependent Variable: GR } & & \\
\hline \multicolumn{2}{|c|}{ Method: ARDL } & & & \\
\hline \multicolumn{5}{|c|}{ Model selection method: Akaike info criterion (AIC) } \\
\hline \multicolumn{5}{|c|}{ Dynamic repressors (4 lags, automatic): I DEF } \\
\hline \multicolumn{3}{|c|}{ Selected Model: ARDL $(1,3,0)$} & & \\
\hline Variable & Coefficient & Std. Error & t-Statistic & Prob.* \\
\hline GR(-1) & 0.891068 & 0.242918 & 3.668187 & 0.0028 \\
\hline $\mathrm{I}$ & -0.500243 & 0.078345 & -6.385158 & 0.0000 \\
\hline $\mathrm{I}(-1)$ & 0.511350 & 0.127425 & 4.012948 & 0.0015 \\
\hline $\mathrm{I}(-2)$ & -0.089350 & 0.072802 & -1.227306 & 0.2415 \\
\hline $\mathrm{I}(-3)$ & 0.183404 & 0.059664 & 3.073924 & 0.0089 \\
\hline DEF & -0.469664 & 0.394797 & -1.189634 & 0.2555 \\
\hline $\mathrm{C}$ & 1.955245 & 1.267377 & 1.542749 & 0.1469 \\
\hline R-squared & 0.818329 & \multicolumn{2}{|c|}{ Mean dependent variable } & 4.492500 \\
\hline Prob(F-statistic) & 0.000347 & & & \\
\hline
\end{tabular}

The model is: 
GR $=0.891 * G R \quad(-1)-0.5 * I+0.51 * I \quad(-1)-0.089 * I \quad(-2) \quad+0.183 * I \quad(-3)-$ $0.47 * \mathrm{DEF}+1.955$

The co-integration equation is:

$\mathrm{D}(\mathrm{GR})=-0.5 * \mathrm{D}(\mathrm{I})+0.089 * \mathrm{D}(\mathrm{I}(-1))-0.183 * \mathrm{D}(\mathrm{I}(-2))-0.47 * \mathrm{D}(\mathrm{DEF})-$ 0.1089*(GR-(0.965*I(-1)-4.3*DEF(-1)+17.95) )

The ARDL model says that growth rate is statistically dependent on Growth at lag one, Inflation rate at lags zero, one and three, and insignificantly related to Inflation at lag two and deficit. Effect of lagged growth is positive, meaning that when growth rate is high it probably will be followed by high rates of growth; and not only the actual but also inflation in past years has an impact on actual growth rate. Again, deficit is not influencing growth rate.

\section{Discussions and conclusions}

Even in the case of Albania results from the study confirm the theoretical expectations and are in line with results of other worldwide research outcomes. Change in growth rate is inversely and statistically related to changes in inflation rate, which means faster growth comes with less inflation. A linear relationship between growth and inflations is right for Albania, but a non-linear form performs better since it fits better this relationship. This is quite coherent with the economic logics that said relationship might not remain linear overtime. A threshold level of inflation is identified by use of threshold regression which determines two states for the relationship growth-inflation over the studied time horizon. In both regimes this relationship is negative and significant, but size of inflation effect is different. Use of switching regression showed that two latent regimes exist with specific regressions. Comparison of these specific regressions shows a significant positive relationship of Growth to inflation in the first regime and a negative relationship in the second regime. The first regime years generally are likely to be years of big changes, but less volatility, in the inflation rate differences. The expected duration of each regime of roughly two years means that volatility of regimes is high, meaning that direction of relationship changes frequently over time. And chances of each regime are almost the same ( 0.54 and 0.46 respectively).

The threshold regression showed that even low levels of inflation changes have impacts on growth rate changes; so there isn't a specific tolerable minimum value of inflation rate.

ARDL model showed that one of the study outcomes is that growth rate in upcoming years is dependent not only on actual inflation rate but also on lagged inflation and growth rates. So the model discovered short-run as well as longer-run multiplier effects of inflation on GDP growth rates. This is important in particular when forecasting future growth rates. 
One of the research outcomes is that fiscal deficit has a significant and huge positive impact on inflation rate, of 2 percentage points. Fiscal deficit seem to have also important though not sufficiently significant positive impact also on growth rates.

Based on study results we can conclude that Albania is for sure an IMF success story in achieving effective macroeconomic stabilization, because IMF macroeconomic stabilization programs have worked in the case of Albania; both control of inflation rate and reduced budget deficit have brought about higher and sustainable GDP growth rates.

\section{References:}

8. Ahmad, N.The Role of Budget Deficit in the Economic Growth of Pakistan, Global Journal of Management and Business Research Economics and Commerce, Volume 13 Issue 5 Version 1.0 Year 2013, Publisher: Global Journals Inc. (USA).

9. Alesina, A., Rodrik, D. (1994). Distributive Politics and Economic Growth, Quarterly Journal of Economics, Volume 109, Issue 2, 1994, 465-490.

10. Andres, J., Hernando, I., Does Inflation Harm Economic Growth? Evidence for the OECD, NBER Working Paper No. 6062, Issued in June 199.

11. Bank of Albania (2012); Bulletin of the Bank of Albania, 6M-1 2012, p 5-8

12. Barro, R. J., (1991).Economic Growth in a Cross Section of Countries, The Quarterly Journal of Economics, Vol. 106, No. 2. (May, 1991), pp. 407-443.

13. Barro., R.J. (2013) Inflation and Economic Growth, Annals of Economics and Finance 14-1, 85-109 (2013). The Quarterly Journal of Economics, Vol. 106, No. 2. (May, 1991), pp. 407-443.

14. Bouman, J. Principles of Macroeconomics, 2006, pp 193.

15. Brooks, Ch. (2008), Introductory Econometrics for Finance, Cambridge University Press, 451-486 p

16. Case, K. E., Fair, R.C., Oster, Sh. M. (2012) Principles of Macroeconomics, Prentice Hall, 477 pp.

17. Datta, K., Mukhopadhyay, Ch.K. (2011a). Relationship between budget deficit and inflation- An econometric study of Indonesia, International Journal of Economic Issues, Vol. 4, No. 2 (July-December, 2011) : 293308.

18. Datta, Kumar, (2011b). Relationship between Inflation and Economic Growth in Malaysia - An Econometric Review, 2011 International Conference on Economics and Finance Research IPEDR vol.4 (2011) (c) (2011) IACSIT Press, Singapore 
19. Dornbusch, R., Fischer, S. (1994). Macroeconomics, Albanian Edition, Publishing House Dituria, 2000, Tirana-Albania pp 85-90, 450-454, 519524.

20. Eviews 9 User’s Guide II, (2015), pp 283-295; 427-478

21. Faraji, K. Kenani M. Impact of inflation on economic growth: a case study of Tanzania, Asian Journal of Empirical Research, journal homepage: http://aessweb.com/journal-detail.php?id=5004.

22. Faria, J.R., Carneiro, F.G., (2001). Does high inflation affect growth in the long and short run? Journal of Applied Economics, Vol. IV, No. 1 (May 2001), 89-105

23. Fatima, G., Ahmed, M., Rehman, W. (2012). Consequential Effects of Budget Deficit on Economic Growth of Pakistan, International Journal of Business and Social Science, Vol. 3 No. 7; April 2012.

24. Fischer, S. (1983). Inflation and Growth, NBER Working Paper No. 1235, Issued in November 1983, pp.18.

25. Ghosh, A., Steven, Ph., Inflation, Disinflation, and Growth, International Monetary Fund, p.44, http://dx.doi.org/10.5089/9781451961188.001.

26. Gilman, M., Harris, M., Mátyás, L.Inflation and Growth: Some Theory and Evidence.

27. Gokal, V., Subrina Hanif, S. (2004). Relationship between inflation and economic growth, Working Paper 2004/04.

28. Gujarati, D. (2004). Basic Econometrics, McGraw-Hill, pp 656-715, 782835.

29. Hayati, N. Rahman, A. (2012). The Relationship between Budget Deficit and Economic Growth from Malaysia's Perspective: An ARDL Approach, 2012 International Conference on Economics, Business Innovation IPEDR vol.38 (2012) (c) (2012) IACSIT Press, Singapore.

30. Heinz D. Kurz \& Neri Salvadori. Theories of Economic Growth - Old and New, https://www.researchgate.net/publication/252313772.

31. Ismaila, M., Imoughele, L. E. (2015). Macroeconomic Determinants of Economic Growth in Nigeria: A Co-integration Approach, International Journal of Academic Research in Economics and Management Sciences 2015, Vol. 4, No.1, http://dx.doi.org/10.6007/IJAREMS/v4-i1/1485.

32. Kasidi, F., Kenani, K. (2013. Impact of inflation on economic growth: a case study of Tanzania. Asian Journal of Empirical Research, 3(4)2013: 363-380.

33. Mankiw, N.G.(2012). Macroeconomics, Worth Publishing House, pp 608.

34. Metin, K. (1998). The Relationship between Inflation and the Budget Deficit in Turkey, Journal of Business \& Economic Statistics, Vol. 16, No. 4 (Oct., 1998), pp. 412-422 
35. Min, L.. Inflation and Economic Growth: Threshold Effects and Transmission Mechanisms, Department of Economics, University of Alberta, 8-14 HM Tory Building, Edmonton, Alberta, Canada, T6G 2H4.

36. Nayab, H. (2015). The Relationship between Budget Deficit and Economic Growth, ISSN 2222-1700 (Paper) ISSN 2222-2855 (Online) Vol.6, No.11, 2015.

37. Pollin, R., Zhu, A. Inflation and Economic Growth: A Cross-Country Non-linear Analysis, Working paper series, 2006, http://www.umass.edu.

38. Pradana, M. Bandula Jayathileke1, Rathnayaka M. Kapila Tharanga Rathnayake, (2013). Testing the Link between Inflation and Economic Growth: Evidence from Asia, in Modern Economy, 2013, 4, 87-92 http://dx.doi.org/10.4236/me.2013.42011 Published Online February 2013 (http://www.scirp.org/journal/me).

39. Reinhart, C.M., Rogoff, K.S., (2010). Growth in a Time of Debt, American Economic Review: Papers \& Proceedings 100 (May 2010): 573-578 http://www.aeaweb.org/articles.php?doi=10.1257/aer.100.2.573.

40. Shuaib, M., O. Ekeria Augustine, A. Ogedengbe Frank (2015). Impact of Inflation Rate on the Economic Growth in Nigeria, British Journal of Economics, Management \& Trade 9(3): 1-11, 2015.

41. Snowdon, B., Vane, H.R. ( 2005). Modern Macroeconomics, pp.826, Edward Elgar Publishing, Inc.

42. Solomon, M., De Wet, W A. The Effect of a Budget Deficit on Inflation: The Case of Tanzania, SAJEMS NS Vol 7 (2004) No 1.

43. Viorica, L. D.The correlation between inflation and economic growth in Romania, Lucrări Ştiinţifice - vol. 53, Seria Zootehnie.

44. Wooldridge, J.M. (2009). Introductory Econometrics. 4th edition, SouthWestern. 